УДК 371.376.58

\title{
ФОРМУВАННЯ ДУХОВНОЇ КУЛЬТУРИ МАЙБУТНЬОГО ВЧИТЕЛЯ ЧЕРЕЗ УЧАСТЬ У ВОЛОНТЕРСЬКОМУ РУСІ
}

\author{
Олена Олійник \\ директор КЗ «Покровський педагогічний коледж» \\ м. Покровськ, Україна \\ ORCID ID 0000-0003-3997-5863 \\ kzppk@ukr.net \\ Любов Макарова \\ кандидат педагогічних наук, доцент \\ К3 «Покровський педагогічний коледж» \\ м. Покровськ, Україна \\ ORCID ID 0000-0003-3867-4624 \\ mlyubov57@gmail.com \\ Валентина Климова
}

заступник директора КЗ «Покровський педагогічний коледж»

м. Покровськ, Україна

ORCID ID 0000-0003-3997-5863

kzppk@ukr.net

Дар'я Кабанова

заступник директора з виховної роботи, викладач КЗ «Покровський педагогічний коледж»

м. Покровськ, Україна

ORCID ID 0000-0003-4128-8592

kabanovadasha89@ukr.net

Галина Рига

практичний психолог, викладач психології

КЗ «Покровський педагогічний коледж»

м. Покровськ, Україна

ORCID ID 0000-0003-3254-6721

Rigagalina03@gmail.com

Анотація. Статтю присвячено актуальній проблемі формування духовної культури майбутніх учителів у системі вищої освіти, яка пов'язана із необхідністю забезпечення гуманістичного розвитку нашого суспільства та духовно-культурного відродження України. Автори наголошують, що моральна складова життедіяльності громадянського суспільства посилюється в часи найбільшої загрози для країни в пропонують власний досвід формування ціннісної спрямованості здобувачів педагогічної освіти КЗ «Покровський педагогічний коледж» через залучення їх до волонтерської діяльності. Доведено, що активна участь у волонтерському русі, сприяє підвищенню показників розвитку до керування емоційнопочуттєвими станами та вміннями передавати свої емоційні стани дітям (під час безперервної педагогічної практики), створювати сприятливу емоційну атмосферу, коли здобувач освіти i діти переживають одні й ті самі позитивні почуття. На достатньо високому рівні розвинені 
готовність до самовдосконалення та самоконтролю, усвідомлення моральних і духовноціннісних орієнтацій.

Ключові слова: професійна підготовка; волонтерство; духовна культура; моральність; етичність; діагностика.

Постановка проблеми в загальному вигляді. Останнє десятиріччя характеризується бурхливим розвитком педагогічної науки, спрямованої на оновлення змісту та методів національної освіти в Україні й приведення їх відповідно до сучасних потреб особи і суспільства. Актуалізується процес формування нової педагогічної парадигми, заснованої на ідеях самоцінності особистості, їі духовності, утвердженні пріоритету загальнолюдських цінностей, гуманістичних духовних ідеалів. Педагогіка переосмислює національні та загальнолюдські цінності такі, як людина, духовність, життя, життєтворчість. Перетворення педагогічної парадигми насамперед зумовлює потребу в новому типі вчителя - висококваліфікованому фахівці, який органічно поєднує якості професіонала та особистісні риси. Актуальною на сьогодні стає проблема формування педагога, наділеного багатим внутрішнім світом, духовними й високоморальними якостями, носія національних і загальнолюдських ідеалів i цінностей.

Сучасні вимоги до якості підготовки майбутніх фахівців зумовлюють необхідність пошуку ефективних шляхів і засобів забезпечення не лише їхньої високої професійної компетентності та конкурентоспроможності на ринку праці, але й загальної і професійної культури, духовності й моральності.

Визначальним чинником успішного розв’язання цього вкрай відповідального завдання постає педагогічна культура. Виступаючи вищим рівнем педагогічної майстерності та інтегральною характеристикою особистості педагога і його професіоналізму, вона може ефективно виконувати свої функції лише за умови формування на надійних підвалинах філософії освіти, своєї загальної людяності й чіткої духовної спрямованості.

Тому проблема формування духовної культури майбутніх учителів у системі вищої освіти $є$ актуальною. До того ж це пов'язано і з необхідністю забезпечення гуманістичного розвитку нашого суспільства та духовнокультурного відродження України.

Аналіз досліджень і публікацій. Проблема формування духовної культури майбутнього вчителя через участь у волонтерському русі розглядається нами в контексті загальних питань морального i духовного життя молоді
(А. Макаренко,
В. Сухомлинський,
О. Богданов,
Н. Болдирев,
I. Бех,

В. Бондаровська, М. Боришевський, Н. Добкіна, Л. Долинська, К. Журба, I. Зязюн, Н. Махова, В. Онищенко, А. Сєрков, О. Скрипченко).

Останнім часом відомі праці, присвячені розвитку духовності в системі філософії педагогічної культури (В. Андрєєв, Л. Архангельський, Н. Баженов, С. Гончаренко, Є. Гришин, С. Кримський, Т. Мишаткіна, В. Наумчик, Р. Охрімчук, В. Писаренко, С. Савченко, Г. Сковорода, С. Чорна, В. Шинкарук 
та ін.). Виокремилися і праці, присвячені цій проблемі безпосередньо (К. Артамонова, М. Старов, О. Силяєва та ін.). Питання професійної підготовки вчителів висвітлено в працях А. Алексюка, А. Бойко, В. Бондаря, В. Гриньової, Н. Кічук, 3. Курлянд, А. Кузнєцової, А. Маркової, О. Мороза, Л. Нечипоренко, I. Прокопенка, О. Пєхоти, Г. Троцко, Г. Шевченко та ін.).

У сучасному розумінні власне духовна культура вчителя визначає моральне і духовне становлення учнів. К. Артамонова під духовною культурою вчителя розуміє інтегральну якість особистості, яка визначає ії спрямованість на створення власного ціннісно-смислового поля; спосіб засвоєння базових ціннісних орієнтацій у професійній життєдіяльності; міру присвоєння й актуалізації духовних цінностей [1].

Під духовною культурою педагога також розуміють його здатність свідомо формувати, засвоювати, зберігати, примножувати та творчо реалізовувати цінності Краси, Добра та Істини у власній професійній діяльності. Духовний світ педагогічного працівника поєднує в собі як особистісну, так і професійну взаємопов'язані сторони.

Духовна культура здобувача вищої освіти як готовність і здатність сприймати i переосмислювати особистісний i духовний досвід виступає професійно значущою складовою його особистості, яка обумовлює його ставлення до себе, до світу, до людей. Формування і розвиток духовної культури майбутніх учителів, що вже володіють певним духовним досвідом, який не завжди усвідомлюється ними з погляду професійної значущості, може бути набутим в умовах здобуття освіти в педагогічному коледжі за умови реалізації потреби майбутніх фахівців у «духовному перетворенні», формуванні здатності до «духовного ототожнення», спрямованості на збагачення духовного досвіду студентів у контексті майбутньої професійної діяльності.

Існує низка факторів, які забезпечують розвиток духовної культури студентів: трансформація змісту освіти в умовах його гуманізації, диверсифікації і гуманітаризації; зміни процесуальних характеристик освіти в коледжі в бік змістового, реалізуючого і смислового планів духовної діяльності майбутнього вчителя тощо.

Як бачимо, моральне становлення особистості завжди пов'язане зі смисловим аспектами розуміння дійсності та оцінними діями особистості. Моральний розвиток визначається у зв'язку з розумінням добра i зла та $\epsilon$ підгрунтям вчинків людини стосовно себе, інших людей і світу загалом. Основи моральної вихованості закладаються в сім'ї. Однак зазначимо і величезну роль педагогічної діяльності вчителя в загальному духовному і моральному розвитку учнів. Моральність - явище соціальне й індивідуальне. Моральні звичаї i традиції охоплюють масові форми поведінки людей, які відіграють вагому роль в інтеграції суспільства. Соціальні впливи на особистість не сприймаються нею пасивно, вони осмислюються, інтерпретуються, наділяючись особистісною значущістю. 
Моральна складова життєдіяльності громадянського суспільства посилюється в часи найбільшої загрози для країни. Тому волонтерська діяльність здобувача освіти в умовах АТО в Україні стає важливим чинником набуття духовного досвіду. У КЗ «Покровський педагогічний коледж» ціннісна спрямованість здобувачів педагогічної освіти здійснюється через залучення їх до волонтерської діяльності. Активна участь вихованців у волонтерському русі допомагає вирішити низку завдань, а саме: формування і розвиток духовної культури, підвищення рівня професійної підготовки, виховання високоморальної особистості вчителя початкових класів тощо.

Для моральної оцінки діяльності волонтерів виокремимо три незалежних оцінювальних судження Ч. Тейлора: 1) поваги щодо іншої людини як суб'єкта морального ставлення; 2) прагнення жити благим життям, що наповнене значенням, на відміну від тривіально-автоматичного існування; 3) прагнення заслужити повагу і шану в межах цього суспільного простору [4].

Важливим моральним аспектом волонтерства $\epsilon$ те, що діяльність волонтерів викликає довіру 3 боку суспільства. Волонтери об'єднують небайдужих людей. Мотивація волонтерства грунтується на відчутті громадянського обов'язку перед нацією, народом, воїнами та жертвами АТО; на моральному обов'язку перед близькими людьми, що беруть участь у бойових діях. Волонтери $\epsilon$ елітою громадянського суспільства, проявом появи нових мас iз високою громадянською свідомістю, що формуються в період Революції гідності та реалізації їі завдань.

Формулювання мети. Мета статті полягає в теоретичному обгрунтуванні та окресленні системи волонтерської роботи випускника педагогічного закладу освіти I-II рівнів акредитації, спрямованої на формування духовної культури майбутнього вчителя.

Результати дослідження. Здобувачі педагогічної освіти Покровського педагогічного коледжу свідомо пов'язали своє майбутнє 3 однією 3 найважливіших професій - професією вчителя. Вони твердо знають, що в основі учительської роботи повинна лежати любов до дітей, повага до старшого покоління, яка передбачає взаєморозуміння, співпрацю, самовіддачу. За роки навчання в педагогічному коледжі вони засвоюють, що завдяки благодійності, милосердю можна будь-яку людину зробити щасливішою.

Освітній процес у педагогічному навчальному закладі I-II рівнів акредитації спрямований на якісну підготовку майбутнього спеціаліста відповідно до вимог сучасного суспільства. Тому поряд із теоретичними використовуються i духовно-практичні впливи (святкові заходи, урочисті церемонії, ритуальні акти тощо), які об'єднують студентів на рівні емоцій, підіймають духовне спілкування на вищий рівень, якого немає в буденному житті. 
Розвиток духовної культури здобувачів вищої освіти КЗ «Покровський педагогічний коледж» ми простежили в процесі роботи волонтерського руху «3 милосердям у серці», який діяв і діє в м. Покровську Донецької області.

Центр волонтерів «3 милосердям у серці» К3 «Покровський педагогічний коледж» створений із числа викладачів і студентів-волонтерів на засадах спільності інтересів для реалізації окресленої мети та завдань.

Головною метою діяльності волонтерського руху стало об'єднання та координація сприяння розвитку волонтерського руху у КЗ «Покровський педагогічний коледж».

Основними завданнями руху стали:

- сприяння розвитку волонтерської діяльності в усіх академічних групах Покровського педагогічного коледжу;

- створення умов для залучення студентів до волонтерської діяльності на основі добровільності і доброчинності;

- сприяння становленню, саморозвитку та самореалізації здобувачів освіти як волонтерів;

- вивчення міжнародного та вітчизняного досвіду з питань волонтерського pyxy;

- співпраця з державними та громадськими організаціями й установами в галузі соціальної допомоги;

- ініціювання та проведення громадських волонтерських акцій на регіональному і місцевому рівнях;

- створення громадської «Школи волонтерів» для підготовки волонтерів до роботи $з$ дітьми та дорослими;

- участь у розробці волонтерських програм і проектів та їхній реалізації.

Творчою групою викладачів КЗ «Покровський педагогічний коледж» (у складі заступника директора 3 виховної роботи, практичного психолога i керівників академічних груп) упродовж шести навчальних років (2011 - 2017pp.) було розроблено та реалізовано спеціальну програму «3 милосердям у серці», виконавцями якої стали 116 здобувачів освіти педагогічного коледжу.

Волонтерська діяльність проводиться за такими напрямками:

- екологічний (збереження екології, благоустрій рідного міста та району: операції «Чисте місто», «Чистий двір», «Прокоф'євська весна єднає молодь», «Посади рослину і збережи іiі», «Екодесант»);

- благодійницький (проведення благодійних акцій «Від серця до серця», «Допоможи вижити», «Ялинка милосердя», «Збережи ялинку», «Турбота», «Допоможи ветерану», «Допоможемо дітям-сиротам», «Гграшка для друга», «Допоможи у біді», «Звичайне диво» та благодійних ярмарків «Дари осені», «Прийшла масляна до нас»);

- шефський (проведення новорічних і різдвяних ранків для дітей-інвалідів Центру реабілітації «Милосердя», дитячого будинку, відвідування та привітання, надання посильної допомоги ветеранам праці та Великої Вітчизняної війни); 
- агітаційний (виступ агітбригад «За здоровий спосіб життя», «Не все в житті варто спробувати», проведення акції «Підтримаємо хворих на СНІД», «Життя без тютюну», виставка плакатів «Шкідливі звички», «Скажи наркотикам $\mathrm{HI} ! »)$.

Реалізувавши Програму, волонтери:

- запровадили творчий звіт про виконану роботу, даючи критичну й обгрунтовану оцінку своїй роботі;

- здійснили аналіз того, що вдалося найкраще, яких помилок можна було б уникнути, чого навчилися, тобто формували життєвий досвід, який допоможе не робити помилок у майбутньому і діяти кожного разу краще;

- ділилися власним набутим досвідом і залучали до спільної роботи інших, продовжуючи суспільну активність надалі;

- поширили волонтерський рух в нашому місті та районі.

Насамкінець усі учасники волонтерського руху «3 милосердям у серці» отримали соціальний досвід, а люди, стосовно яких була виявлена благодійність, отримали емоційну й моральну підтримку через насичення їхнього життя спілкуванням, цікавими подіями, культурними заходами. Діти з обмеженими можливостями та їхні родини отримали насамперед моральну, емоційну та матеріальну підтримку, відчули небайдужість суспільства до себе, діти, позбавлені батьківського піклування, - любов навколишніх.

Отже, одним із першочергових завдань у Покровському педагогічному коледжі став розвиток і задоволення моральних, естетичних запитів у процесі активної творчої діяльності засобами позааудиторної роботи. Завдяки власній благодійній діяльності в усіх учасників волонтерського руху «З милосердям у серці» систематично виховувалися моральні принципи (людяність, ввічливість, уважність, скромність, тактовність, делікатність, пунктуальність, дисциплінованість), вироблялися моральні потреби майбутніх учителів вірити й любити, формувалася внутрішня культура (світогляд, моральні переконання, загальний розвиток особистості, ï знання, інтереси, потреби), спрямовувалася зовнішня поведінка (виконання правил внутрішнього розпорядку коледжу, поведінки в громадських місцях, спонукання студентської молоді до безкорисливих і благородних учинків), формувалася культура взаємин у спілкуванні і праці; культура мовлення; культура зовнішнього вигляду. Як наслідок - усі ці принципи стають для них нормою життя.

Для діагностування розвитку рівня духовної культури здобувачів освіти педагогічного коледжу під час дослідження застосувалась діагностика Н. Вінника «Духовна культура особистості педагога». Їм пропонувалось оцінити силу своїх професійно-психологічних прагнень (за п'ятибальною шкалою (А) i ступінь повноти їхнього здійснення в навчально-професійній діяльності (за п’ятибальною шкалою (Б). Аналіз отриманих результатів ми здійснювали за такими параметрами:

- усвідомлення професійних знань на ціннісному рівні; 
- $\quad$ любов до дітей;

- $\quad$ рефлексія професійних цінностей;

- духовне спілкування;

- $\quad$ гуманістична спрямованість;

- гармонійний саморозвиток;

- творча та духовна самореалізація;

- $\quad$ набуття та реалізація духовного досвіду;

- $\quad$ інтелектуально-творчі прагнення;

- психічна саморегуляція;

- естетичне використання професійних знань.

Дослідивши рівень розвитку духовної культури студентів I курсу у 2011 2012 н.р., ми отримали такі результати (табл. 1):

Таблиця 1.

\begin{tabular}{|c|c|c|c|c|c|c|c|c|c|c|c|}
\hline \multirow{3}{*}{ № } & \multirow{3}{*}{ Види духовних цінностей } & \multicolumn{5}{|c|}{ Сила прагнення } & \multicolumn{5}{|c|}{ Ступінь реалізації } \\
\hline & & 1 & 2 & 3 & 4 & 5 & 1 & 2 & 3 & 4 & 5 \\
\hline & & \multicolumn{10}{|c|}{ Пріоритети студентів (у \%) } \\
\hline 1 & $\begin{array}{l}\text { Усвідомлення професійних знань на } \\
\text { ціннісному рівні }\end{array}$ & 0 & 14 & 13 & 63 & 10 & 15 & 72 & 13 & 0 & 0 \\
\hline 2 & Любов до дітей & 0 & 0 & 4 & 16 & 80 & 0 & 0 & 16 & 42 & 42 \\
\hline 3 & Рефлексія професійних цінностей & 0 & 2 & 14 & 66 & 18 & 17 & 24 & 32 & 20 & 7 \\
\hline 4 & Духовне спілкування & 0 & 8 & 19 & 5 & 68 & 24 & 58 & 17 & 1 & 0 \\
\hline 5 & Гуманістична спрямованість & 3 & 0 & 4 & 80 & 13 & 0 & 4 & 66 & 18 & 12 \\
\hline 6 & Гармонійний саморозвиток & 0 & 0 & 3 & 34 & 63 & 8 & 12 & 73 & 7 & 0 \\
\hline 7 & Творча та духовна самореалізація & 0 & 0 & 18 & 38 & 44 & 15 & 19 & 48 & 18 & 0 \\
\hline 8 & $\begin{array}{l}\text { Набуття та реалізація духовного } \\
\text { досвіду }\end{array}$ & 2 & 9 & 14 & 19 & 56 & 13 & 34 & 53 & 0 & 0 \\
\hline 9 & Інтелектуально-творчі прагнення & 4 & 15 & 7 & 51 & 23 & 10 & 3 & 87 & 0 & 0 \\
\hline 10 & Психічна саморегуляція & 0 & 0 & 8 & 4 & 88 & 34 & 45 & 18 & 2 & 1 \\
\hline 11 & $\begin{array}{lc}\text { Естетичне } & \text { використання } \\
\text { професійних знань } & \\
\end{array}$ & 9 & 4 & 4 & 69 & 14 & 19 & 22 & 16 & 22 & 21 \\
\hline
\end{tabular}

Результати дослідження засвідчили про недостатній рівень сформованості духовних цінностей, однак, оцінюючи силу своїх професійно-психологічних прагнень у духовному розвитку, першокурсники зазначили про своє бажання розвивати моральні та духовні цінності.

Урахування означених потреб викликало завдання стосовно формування й підвищення рівня духовної культури майбутніх педагогів, що могло б забезпечити зворотний зв'язок для посилення усвідомленого прагнення оволодіти новими надбаннями духовної культури й розширити духовний світ.

Досліджуваній групі здобувачів освіти ми запропонували долучитись до роботи студентського волонтерського молодіжного руху «З милосердям у 
серці», який співпрацює 3 Центром соціальної реабілітації дітей-інвалідів «Милосердя», відділенням міської лікарні для ВІЛ-інфікованих дітей, Покровським дитячим будинком, ветеранами педагогічної праці і ветеранами Другої світової війни, службою соціального захисту населення та організацією Червоного Хреста м. Покровська. Упродовж шести років $62 \%$ досліджуваних здобувачів освіти брали активну участь у реалізації програми студентського волонтерського руху «З милосердям у серці».

Наприкінці 2016 - 2017 н.р. серед тих четвертокурсників, які брали участь у дослідженні, ми прослідкували рівень розвитку їхньої духовної культури (критерії внесено до таблиці 1) й отримали такі результати (діаграма 1).

\begin{tabular}{|c|l|}
\hline $\begin{array}{c}\text { № } \\
\text { цінності }\end{array}$ & \multicolumn{1}{c|}{ Види духовних цінностей } \\
\hline 1 & Усвідомлення професійних знань на ціннісному рівні \\
\hline 2 & Любов до дітей \\
\hline 3 & Рефлексія професійних цінностей \\
\hline 4 & Духовне спілкування \\
\hline 5 & Гуманістична спрямованість \\
\hline 6 & Гармонійний саморозвиток \\
\hline 7 & Творча та духовна самореалізація \\
\hline 8 & Набуття та реалізація духовного досвіду \\
\hline 9 & Інтелектуально-творчі прагнення \\
\hline 10 & Психічна саморегуляція \\
\hline 11 & Естетичне використання професійних знань \\
\hline
\end{tabular}

Таблиия 1

Діаграма 1

Порівняння рівня розвитку духовної культури досліджуваної вибірки студентів у 2011 н.p. та 2015 н.р. студентів

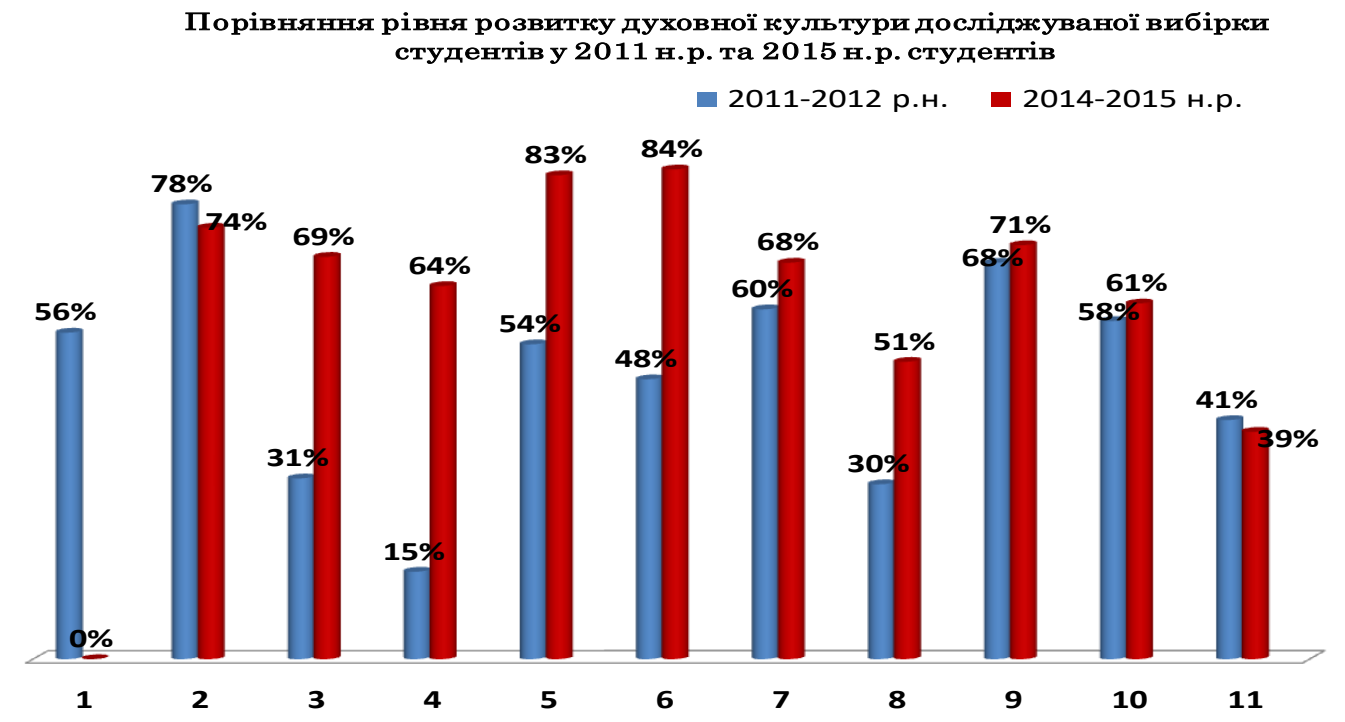

Професіоналізм педагога: теоретичні й методичні аспекти. - Вип. 8. - Слов’янськ, 2018. 
Результати дослідження свідчать, що в здобувачів освіти, які брали активну участь у волонтерському русі, спостерігаються високі показники розвитку до керування емоційно-почуттєвими станами та вміннями передавати свої емоційні стани дітям (під час безперервної педагогічної практики), створювати сприятливу емоційну атмосферу, коли здобувач освіти і діти переживають одні й ті самі позитивні почуття. На достатньо високому рівні розвинені готовність до самовдосконалення та самоконтролю, усвідомлення моральних і духовно-ціннісних орієнтацій.

Отже, у процесі формування духовної культури чітко вибудовується «Яконцепція» майбутніх учителів, упорядковуються мотиви, мислення спрямовується на розв'язання найважливіших проблем, досягається гармонійне співвідношення фізичної, емоційно-почуттєвої та інтелектуальної сфер.

Висновки 3 дослідження і перспективи подальших розвідок у цьому напрямі. Результати практичної діяльності волонтерського руху «З милосердям у серці» доводять, що молодь України вміє знаходити шляхи реалізації великих проблем суспільства через реальні дії студентської громади. Створюючи умови для систематичної роботи, спрямованої на активну волонтерську діяльність, педагогічний коледж готує фахівця, який вирізняється більш високим рівнем духовної культури, зростанням духовних потреб, інтересів і прагненням до творчої діяльності. А професійна підготовка майбутнього вчителя, зорієнтована на духовне зростання, $є$ передумовою ефективної педагогічної діяльності.

\section{СПИСОК ВИКОРИСТАНИХ ДЖЕРЕЛ}

1. Артамонова, Е.И. (2000). Философско-педагогические основы развития духовной культуры учителя. (Дис. д-ра пед. наук). Москва, Россия.

2. Вайнола, Р.Х., Капська, А.Й. і Комарова, Н.М. (1999). Волонтерський рух в Украйні: тендениії розвитку. Київ, Україна: Академпрес.

3. Звєрєва, І. і Лактіонова, Г. (2001). Підготовка волонтерів та їх роль у реалізачіi соиіальних проектів. Київ, Україна: Науковий світ.

4. Taylor, C. (1989). Sources of the Self: the Making of the Modern Identity. Cambridge: Harvard University Press.

\section{ФОРМИРОВАНИЕ ДУХОВНОЙ КУЛЬТУРЫ БУДУЩЕГО УЧИТЕЛЯ ЧЕРЕЗ УЧАСТИЕ В ВОЛОНТЕРСКОМ ДВИЖЕНИИ}

\section{Елена Олейник}

директор КУ «Покровский педагогический колледж»

г. Покровск, Украина

ORCID ID 0000-0003-3997-5863

kzppk@ukr.net

\section{Любовь Макарова}

кандидат педагогических наук, доцент

КУ «Покровский педагогический колледж»

г. Покровск, Украина 
О. ОЛІЙНИК, Л. МАКАРОВА, В. КЛИМОВА, Д. КАБАНОВА, Г.РИГА

Формування духовної культури майбутнього вчителя через участь у волонтерському русі

$$
\begin{gathered}
\text { ORCID ID 0000-0003-3867-4624 } \\
\text { mlyubov57@ gmail.com } \\
\text { Валентина Климова }
\end{gathered}
$$

заместитель директора КУ «Покровский педагогический колледж»

$$
\begin{gathered}
\text { г. Покровск, Украина } \\
\text { ORCID ID 0000-0003-3997-5863 } \\
\text { kzppk@ukr.net } \\
\text { Дарья Кабанова }
\end{gathered}
$$

заместитель директора по воспитательной работе, преподаватель КУ «Покровский педагогический колледж»

г. Покровск, Украина

ORCID ID 0000-0003-4128-8592

kabanovadasha89@ukr.net

\title{
Галина Рига
}

практический психолог, преподаватель психологии

КУ «Покровский педагогический колледж»

$$
\begin{gathered}
\text { г. Покровск, Украина } \\
\text { ORCID ID 0000-0003-3254-6721 } \\
\text { Rigagalina03@gmail.com }
\end{gathered}
$$

Аннотация. Статья посвящена актуальной проблеме формирования духовной культуры будущих учителей в системе высшего образования, которая связана с необходимостью обеспечения гуманистического развития общества и духовно-культурного возрождения Украины. Авторы отмечают, что моральная составляющая жизнедеятельности гражданского общества усиливается во времена наибольшей угрозы для страны и предлагают собственный опыт формирования ценностной направленности соискателей педагогического образования КУ «Покровский педагогический колледж» через привлечение их к волонтерской деятельности. Доказано, что активное участие в волонтерском движении, способствует повышению показателей развития к управлению эмоционально-чувственными состояниями и умениями передавать свои эмоциональные состояния детям (при непрерывной педагогической практике), создавать благоприятную эмоциональную атмосферу, когда соискатель образования и дети переживают одни и те же положительные чувства. На достаточно высоком уровне развиты готовность к самосовершенствованию и самоконтролю, осознание нравственных и духовно-ценностных ориентаций.

Ключевые слова: профессиональная подготовка; волонтерство; духовная культура; нравственность; этичность; диагностика.

\section{DEVELOPING SPIRITUAL CULTURE OF FUTURE TEACHER THROUGH PARTICIPATING IN VOLUNTEER MOVEMENT}

\author{
Olena Oliinyk \\ Director of Public Institution "Pokrovsky Pedagogical College" \\ Pokrovsk, Ukraine \\ ORCID ID 0000-0003-3997-5863 \\ kzppk@ukr.net \\ Liubov Makarova
}




\section{Candidate of Pedagogical Sciences, Associate Professor Public Institution "Pokrovsky Pedagogical College" Pokrovsk, Ukraine ORCID ID 0000-0003-3867-4624 mlyubov57@gmail.com \\ Valentyna Klimova}

Deputy Director of Public Institution "Pokrovsky Pedagogical College" Pokrovsk, Ukraine ORCID ID 0000-0003-3997-5863

kzppk@ukr.net

\section{Daria Kabanova}

Deputy Director in Upbringing Activities, Teacher of Public Institution "Pokrovsky Pedagogical College" Pokrovsk, Ukraine ORCID ID 0000-0003-4128-8592 kabanovadasha89@ukr.net

\section{Halyna Ryha}

Practical Psychologist, Psychology Teacher

Public Institution "Pokrovsky Pedagogical College"

Pokrovsk, Ukraine

ORCID ID 0000-0003-3254-6721

Rigagalina03@gmail.com

Abstract. The article is devoted to the relevant issue of developing spiritual culture of future teachers in the system of higher education that is connected with the necessity to maintain the humanistic development of the society and spiritual and cultural recovery of Ukraine. The problem of developing spiritual culture of future teachers through participating in volunteer movement is considered by the authors in the context of general issues of youth's moral and spiritual life (A. Makarenko, V. Sukhomlynskyi， O. Bohdanova， N. Boldyrev， I. Bekh， V. Bondarovska, M. Boryshevskyi, N. Dobkina, L. Dolynska, K. Zhurba and others).

The authors distinguish a number of factors that contribute to the students' spiritual development: transforming the content of education in the conditions of its humanization, diversification and humanitarization; changes of processual characteristics of education in the college to the content, implementing and meaningful sides of spiritual activities of a future teacher.

The purpose of the article is to justify theoretically and characterize the system of volunteer work of graduate of pedagogical educational institution with I-III level of accreditation which is aimed at developing future teachers' spiritual culture.

The authors emphasize that the moral component of life activities in civil society intensifies in times of greatest threat to the country and offer their own experience of developing the value orientation of the students of the pedagogical specialties at "Pokrovsk Pedagogical College" through engaging them into volunteer activities. It is proved that active participation in the volunteer movements contributes to increasing the indicators of development for managing emotional and sensual states and the ability to transfer their emotional states to children (during continuous pedagogical practice), for creating a favorable emotional atmosphere when the students and children experience the same positive feelings. Readiness for self-improvement and self-control, and awareness of moral and spiritual values are developed at a rather high level.

Key words: professional training; volunteering; spiritual culture; morality; ethics; diagnostics. 
О. ОЛІЙНИК, Л. МАКАРОВА, В. КЛИМОВА, Д. КАБАНОВА, Г.РИГА

Формування духовної культури майбутнього вчителя через участь у волонтерському русі

\section{REFERENCES (TRANSLATED AND TRANSLITERATED)}

1. Artamonova, E.I. (2000). Philosophical and pedagogical foundations for developing the spiritual culture of the teacher. (Doctoral dissertation). Moscow, Russia.

2. Vainola, R. Kh., Kapskaya, A. Y. and Komarova, N. M. (1999). Volunteer Movement in Ukraine: Development Trends. Kiev, Ukraine: Akadempres.

3. Zvereva, I. and Laktionova H. (2001). Training of volunteers and their role in implementing social projects. Kyiv, Ukraine: Naukovyi svit.

4. Taylor, C. (1989). Sources of the Self: the Making of the Modern Identity. Cambridge: Harvard University Press.

Матеріали надійшли до редакції 22.11.2018 р. 